\title{
Deoxyribonucleic Acid Hybridizations Among Strains of Streptococcus salivarius and Streptococcus bovis
}

\author{
A. L. COYKENDALL* AND K. B. GUSTAFSON \\ Department of Oral Diagnosis, School of Dental Medicine, University of Connecticut Health Center, Farmington, \\ Connecticut 06032
}

\begin{abstract}
The genetic relationships among 33 streptococci that were identified as Streptococcus salivarius or Streptococcus bovis and were isolated from humans were determined by deoxyribonucleic aciddeoxyribonucleic acid hybridization on membrane filters. The phenotypic characteristics of these bacteria were determined by their action on 20 substrates in a commercially prepared system, as well as by colony morphology and conventional tests. The $S$. salivarius strains were biochemically heterogeneous but genetically homogeneous. Although there were some phenotypic similarities between $S$. bovis and $S$. salivarius, these two species were genetically distinet. Within $S$. bovis there was genetic heterogeneity. Typical $S$. bovis strains $(S$. bovis biotype $I$ ) were genetically homologous with some, but not all, of the $S$. bovis variant strains $(S$. bovis biotype II). Other $S$. bovis biotype II strains formed a separate genetic group, the members of which were biochemically somewhat different from other $S$. bovis biotype II strains.
\end{abstract}

Streptococcus bovis has become medically important since it was discovered to be a frequent cause of endocarditis $(13,19,20,30,35)$ and to be more common in the bowels of patients with colon diseases, including carcinomas $(23,24$, $31,36)$. Isolates from such human sources ferment mannitol, usually ferment inulin, and produce an extracellular glucan from sucrose $(13,34)$. These typical strains are called Streptococcus bovis biotype I to differentiate them from strains of a variant type called Streptococcus bovis biotype II, which do not ferment mannitol or inulin and do not produce glucan $(13,34)$. As is usual with such divisions, there are strains whose characteristics put them midway between the biotypes (for example, mannitol fermentation but no glucan production). In addition, some members of the common human commensal Streptococcus salivarius resemble Streptococcus bovis because they have similar biochemical traits and may react with Lancefield group D antiserum or grow on bile-esculin agar (37) or both. Like Streptococcus bovis, Streptococcus salivarius produces a polymer, usually levan $(21,32)$, from sucrose, and the two species can produce similar colonies on sucrose agar.

To clarify the relationships among strains identified as Streptococcus salivarius, Streptococcus bovis biotype I, and Streptococcus bovis biotype II, we compared the base sequence similarities of their deoxyribonucleic acids (DNAs) by using DNA-DNA hybridization.

\section{MATERIALS AND METHODS}

The strains used in this study are listed in the tables (see below). Strains whose designations begin with CDC were obtained from the Centers for Disease Control, Atlanta, Ga.; strains whose designations begin with COL were obtained from the Central Public Health Laboratories, Colindale, England; and strains whose designations begin with $\mathrm{MG}$ were obtained from The Massachusetts General Hospital, Boston. Other strains were obtained from clinics at the University of Connecticut Health Center, Farmington. Strain 13419 was a subculture of Streptococcus salivarius ATCC 13419, a strain whose nutrition and extracellular polymers have been exam-

\footnotetext{
* Corresponding author.
}

ined $(5,21)$. Strain TOVE- $\mathrm{R}$ is a Streptococcus salivarius strain which produces copious extracellular glucans from sucrose (40). Strain COL005 is a subculture of Streptococcus bovis NCTC 8133, which was a human isolate. Some of these strains were typical of Streptococcus salivarius or Streptococcus bovis, and some were biochemically, serologically, or colonially atypical (see below). We believe that all of these streptococci are of human origin. Pure cultures were established and maintained in Todd-Hewitt broth supplemented with $1 \%$ extra glucose and $\mathrm{CaCO}_{3}$. Cultures grown for the production of DNA or for biochemical tests were Gram stained and streaked onto blood agar plates to certify their purity.

Biochemical and cultural characterization. Each strain was tested for several biochemical reactions by using the Rapid Strep system (DMS Laboratories, Flemington, N.J.), a commercial test strip system which we and other workers have found useful for the identification of streptococci $(1,7$, 15, 38; Gustafson and Coykendall, manuscript in preparation). This system tests for the production of acetoin, $\alpha$-galactosidase, $\beta$-galactosidase, $\beta$-glucuronidase, pyrrolidonylarylamidase, alkaline phosphatase, and leucine arylamidase, the hydrolysis of hippurate, esculin, and arginine, and the fermentation of arabinose, glycogen, inulin, lactose, mannitol, raffinose, ribose, sorbitol, starch, and trehalose. Conventional methods were used for several strains to test for growth on bile-esculin agar (26) and for the production of urease (26) and hydrogen peroxide (42). Colony morphology was observed on casein-soy agar (Trypticase soy agar; BBL Microbiology Systems, Cockeysville, Md.) supplemented with $10 \%$ sheep blood and on mitis salivarius agar (Difco Laboratories, Detroit, Mich.), which contains $5 \%$ sucrose, which promotes production of glucans and levans. Extracellular polysaccharides were not analyzed, but we recorded whether the colonies were typical of Streptococcus salivarius (21) or Streptococcus bovis (2) or were flat or low convex, which was interpreted to represent a lack of appreciable extracellular polysaccharide production. Streptococci which were identified as Streptococcus bovis strains were tested for the Lancefield group D antigen with a latex bead agglutination system (Streptex; Wellcome Laboratories, Research Triangle Park, N.C.). Many Streptococcus bovis isolates fail to react in this system $(6,14,37)$. 
TABLE 1. Biochemical and cultural characteristics and DNA hybridization of Streptococcus salivarius strains ${ }^{a}$

\begin{tabular}{|c|c|c|c|c|c|c|c|c|c|c|}
\hline \multirow[b]{2}{*}{ Strain } & \multicolumn{7}{|c|}{ Biochemical tests } & \multirow{2}{*}{$\begin{array}{l}\text { Colony } \\
\text { morphology }\end{array}$} & \multirow[b]{2}{*}{ Rapid strep system identity" } & \multirow{2}{*}{$\stackrel{\%}{\text { Hybridization }}{ }^{d}$} \\
\hline & $\begin{array}{l}\text { Voges- } \\
\text { Proskauer }\end{array}$ & Esculin & Trehalose & Inulin & Raffinose & Starch & Urease & & & \\
\hline AC002 & $t^{\circ}$ & + & - & + & + & + & - & Sal & Streptococcus salivarius & 113 \\
\hline KB005 & + & + & + & - & + & - & + & Sal & Streptococcus salivarius & 100 \\
\hline MG561 & + & + & + & + & + & + & + & None & Streptococcus salivarius & 103 \\
\hline MG568 & + & + & + & - & + & + & + & Sal & Streptococcus salivarius & 119 \\
\hline TOVE-R & + & + & - & w & + & - & + & Bov & Streptococcus salivarius & 102 \\
\hline UC8105 & + & + & + & + & + & + & + & Sal & Streptococcus salivarius & 61 \\
\hline CDC009 & + & + & + & - & + & + & - & Sal & $\mathrm{NI}^{f}$ & 121 \\
\hline CM101 & + & + & - & - & + & - & + & Sal & Streptococcus salivarius & 99 \\
\hline CM104 & + & + & + & + & + & + & - & Sal & Streptococcus salivarius & 113 \\
\hline 13419 & + & + & + & - & + & + & - & Sal & Streptococcus salivarius & 114 \\
\hline MG4 & - & + & + & + & + & t & - & Sal & Streptococcus pneumoniae & 95 \\
\hline COL001 & - & - & + & - & - & - & - & None & Streptococcus mitis & 97 \\
\hline $\mathrm{CDC} 010$ & - & + & - & - & - & - & - & Sal & $\begin{array}{l}\text { Streptococcus sanguis or } \\
\text { Streptococcus mitis }\end{array}$ & 125 \\
\hline CDC013 & + & + & + & + & + & + & - & Sal & Streptococcus salivarius & 88 \\
\hline CDC014 & + & + & + & - & + & + & + & Sal & Streptococcus salivarius & 95 \\
\hline CDC015 & + & + & - & - & - & - & - & None & $\begin{array}{l}\text { Streptococcus sanguis or } \\
\text { Streptococcus mitis }\end{array}$ & 51 \\
\hline
\end{tabular}

"All Streptococcus salivarius strains were positive for leucine arylamidase, $\beta$-galactosidase (except strain AC002), and lactose and negative for hippurate, pyrrolidonylarylamidase, $\alpha$-galactosidase, $\beta$-glucuronidase, alkaline phosphatase, arginine, ribose, arabinose, mannitol, sorbitol, and glycogen (except strain CDC009).

${ }^{b}$ Colony morphology on Mitis-salivarius agar. Sal, Colonies typical of Streptococcus salivarius strains; Bov, colonies resemble colonies of typical Streptococcus bovis biotype I strains; Sang, colonies resemble the hard adherent colonies of Streptococcus sanguis: None, flat or low convex colonies apparently devoid of polysaccharide.

"Identity as determined by the Rapid Strep system.

${ }^{d}$ Levels of hybridization with labeled DNA from strain KB005, expressed as percentages of the homologous control value.

+ , Positive reaction; - , negative reaction; $w$, weak reaction.

NI, Not identified.

We recorded agglutination (or the lack of it) for each strain after tests were performed according to the directions of the manufacturer.

Cell lysis and extraction of DNA. The general method used to lyse streptococci has been described previously (8). Briefly, log phase cells grown in Todd-Hewitt broth supplemented with $1 \%$ extra glucose were treated with penicillin and then harvested and lysed with lysozyme and detergents. Streptococcus salivarius was difficult to lyse, and the method was modified as follows. One liter of broth that had been warmed overnight in an anaerobic chamber was inoculated with $100 \mathrm{ml}$ of freshly grown cells. Growth was monitored by measuring optical density. The $\mathrm{pH}$ was periodically adjusted to about 7.0 with $\mathrm{NaOH}$. In late log phase $10 \mathrm{U}$ of penicillin $\mathrm{G}$ per ml was added, and growth was allowed to continue with $\mathrm{pH}$ adjustments as described above.

When growth slowed, the cells were harvested by centrifugation and washed with deionized water. The washed cells were suspended in about $30 \mathrm{ml}$ of $10 \mathrm{mM}$ phosphate buffer $(\mathrm{pH} 7)$ and incubated at $37^{\circ} \mathrm{C}$ for $1 \mathrm{~h}$ to allow catabolism of any stored polysaccharide. The cells were then centrifuged, suspended in $20 \mathrm{ml}$ of $0.1 \times \mathrm{SSC}(1 \times \mathrm{SSC}$ is $0.15 \mathrm{M} \mathrm{NaCl}$ plus $0.015 \mathrm{M}$ sodium citrate) supplemented with $10 \mathrm{mg}$ of lysozyme (Sigma Chemical Co., St. Louis, Mo.), and incubated at $37^{\circ} \mathrm{C}$ for $1 \mathrm{~h}$. The suspension was brought to $55^{\circ} \mathrm{C}$ and incubated for $1 \mathrm{~h}$ with $200 \mathrm{U}$ of mutanolysin (Sigma). Then, $10 \times$ SSC was added to bring the salt concentration to that of $1 \times$ SSC, and $0.5 \mathrm{ml}$ of sodium dodecyl sulfate was added while the cell suspension was warmed to $60^{\circ} \mathrm{C}$. The detergent lysed the cells, and the thick crude product was held at $60^{\circ} \mathrm{C}$ for about $20 \mathrm{~min}$. Finally, the material was incubated overnight at $37^{\circ} \mathrm{C}$ with $1 \mathrm{ml}$ of $5 \%$ protease from Streptomyces griseus (catalog no. P-5147; Sigma). The DNA was purified by phenol and chloroform extractions, treatment with ribonuclease, and precipitations with ethanol and isopropanol (27). Streptococcus bovis was much easier to lyse, and mutanolysin was not needed.

For radioactively labeled DNA, $500 \mathrm{ml}$ of Todd-Hewitt broth was supplemented with $1 \mathrm{mCi}$ of $\left[\right.$ methyl $\left.-{ }^{3} \mathrm{H}\right]$ thymidine.

Determination of DNA base contents. Base compositions (guanine-plus-cytosine $[\mathrm{G}+\mathrm{C}]$ contents) were determined by thermal denaturation in $1 \times$ SSC (28). The absorbance of the DNA sample was recorded continually while the sample was heated $0.5^{\circ} \mathrm{C} / \mathrm{min}$.

DNA hybridization. DNA was hybridized on membrane filters in $30 \%(\mathrm{vol} / \mathrm{vol})$ dimethyl sulfoxide in $2 \times \mathrm{SSC}$ as described by Legault-Démare et al. (25). We proceeded as previously described (10), with one modification. DeLey and Tijtgat (12) found that some DNA is released from filters in the first hour and thus is available to compete for the labeled DNA. Therefore, we incubated the filters (with their bound DNA) for $1 \mathrm{~h}$ in the dimethyl sulfoxide- $2 \times$ SSC solvent and then exchanged it for fresh solvent. Then $1 \mu \mathrm{g}$ of sonically sheared $\left[{ }^{3} \mathrm{H}\right] \mathrm{DNA}$ was added. All experiments were done in duplicate.

Reassociation was allowed to proceed for $16 \mathrm{~h}$ at $48^{\circ} \mathrm{C}$, after which the filters were rinsed in warm solvent and dried and the amount of bound, hybridized $\left[{ }^{3} \mathrm{H}\right] \mathrm{DNA}$ was estimated by liquid scintillation counting. Each experiment included filters bearing DNA from the same strain that supplied the labeled DNA (the homologous control) and filters bearing Escherichia coli DNA (the negative control) or filters with no DNA (the blank). The level of DNA homology between strains was measured by comparing the amount of $\left[{ }^{3} \mathrm{H}\right] \mathrm{DNA}$ bound to the unlabeled DNA of each strain with the amount of $\left[{ }^{3} \mathrm{H}\right] \mathrm{DNA}$ bound to the DNA in the homolo- 
TABLE 2. Biochemical and cultural characteristics of Streptococcus bovis strains ${ }^{a}$

\begin{tabular}{|c|c|c|c|c|c|c|c|c|c|c|c|c|}
\hline \multirow[b]{2}{*}{ Strain } & \multicolumn{9}{|c|}{ Biochemical tests } & \multirow[b]{2}{*}{$\begin{array}{l}\text { Colony } \\
\text { morph- } \\
\text { ologyc }\end{array}$} & \multicolumn{2}{|c|}{ Identity as determined by: } \\
\hline & $\begin{array}{l}\beta \text {-Glucu- } \\
\text { ronidase }\end{array}$ & $\begin{array}{l}\beta \text {-Galac- } \\
\text { tosidase }\end{array}$ & $\begin{array}{l}\text { Man- } \\
\text { nitol }\end{array}$ & $\begin{array}{c}\text { Tre- } \\
\text { halose }\end{array}$ & Inulin & Starch & Glycogen & $\begin{array}{l}\text { Bile- } \\
\text { esculin }\end{array}$ & $\begin{array}{l}\text { Group } \\
\text { D anti- } \\
\text { serum }^{b}\end{array}$ & & $\begin{array}{l}\text { Rapid strep } \\
\text { system }\end{array}$ & $\begin{array}{c}\text { DNA } \\
\text { hybridization }\end{array}$ \\
\hline $\mathrm{CDC} 003$ & $-{ }^{d}$ & - & + & + & + & + & + & + & + & Bov & $\begin{array}{l}\text { Streptococcus } \\
\quad \text { bovis biotype } \\
\text { I }\end{array}$ & $\begin{array}{l}\text { Streptococcus } \\
\quad \text { bovis } \\
\text { biotype I }\end{array}$ \\
\hline CDC001 & - & - & + & + & + & + & + & + & - & None & $\begin{array}{l}\text { Streptococcus } \\
\quad \text { bovis biotype } \\
\text { I }\end{array}$ & $\begin{array}{l}\text { Streptococcus } \\
\quad \text { bovis } \\
\text { biotype I }\end{array}$ \\
\hline $\mathrm{CDC002}$ & - & - & + & + & + & + & + & + & - & Sang & $\begin{array}{l}\text { Streptococcus } \\
\quad \text { bovis biotype } \\
\text { I }\end{array}$ & $\begin{array}{l}\text { Streptococcus } \\
\text { bovis } \\
\text { biotype I }\end{array}$ \\
\hline MGEath & - & + & + & + & - & + & + & - & - & Bov & $\begin{array}{l}\text { Streptococcus } \\
\quad \text { bovis biotype } \\
\text { I }\end{array}$ & $\begin{array}{l}\text { Streptococcus } \\
\text { bovis } \\
\text { biotype I }\end{array}$ \\
\hline COL003 & - & - & - & - & - & - & - & + & + & None & $\begin{array}{l}\text { Streptococcus } \\
\text { bovis biotype } \\
\text { II/1 or } \\
\text { Streptococcus } \\
\text { salivarius }\end{array}$ & $\begin{array}{l}\text { Streptococcus } \\
\quad \text { bovis } \\
\text { biotype II/1 }\end{array}$ \\
\hline CDC011 & - & - & - & - & - & - & - & + & - & None & $\begin{array}{l}\text { Streptococcus } \\
\text { bovis biotype } \\
\text { II/1 or } \\
\text { Streptococcus } \\
\text { salivarius }\end{array}$ & $\begin{array}{c}\text { Streptococcus } \\
\text { bovis } \\
\text { biotype II/1 }\end{array}$ \\
\hline CDC012 & - & - & - & - & - & + & + & + & + & None & $\begin{array}{l}\text { Streptococcus } \\
\text { bovis biotype } \\
\text { II/1 or } \\
\text { Streptococcus } \\
\text { salivarius }\end{array}$ & $\begin{array}{l}\text { Streptococcus } \\
\text { bovis } \\
\text { biotype II/1 }\end{array}$ \\
\hline COL005 & - & w & - & - & - & + & - & + & - & Bov & $\mathrm{NI}^{e}$ & $\begin{array}{l}\text { Streptococcus } \\
\quad \text { bovis } \\
\text { biotype II/1 }\end{array}$ \\
\hline MGFras & - & + & - & - & - & + & - & + & - & None & $\begin{array}{l}\text { Streptococcus } \\
\quad \text { bovis biotype } \\
\text { II/1 or } \\
\text { Streptococcus } \\
\text { salivarius }\end{array}$ & $\begin{array}{l}\text { Streptococcus } \\
\text { bovis } \\
\text { biotype II/1 }\end{array}$ \\
\hline CDC018 & - & - & - & - & - & + & - & - & - & Sal & $\begin{array}{l}\text { Streptococcus } \\
\text { bovis biotype } \\
\text { II } / 1\end{array}$ & $\begin{array}{l}\text { Streptococcus } \\
\text { bovis } \\
\text { biotype II/1 }\end{array}$ \\
\hline CDC008 & + & + & - & + & - & - & - & + & + & Sal & $\begin{array}{l}\text { Streptococcus } \\
\text { bovis biotype } \\
\mathrm{II} / 2\end{array}$ & $\begin{array}{l}\text { Streptococcus } \\
\text { bovis } \\
\text { biotype II/2 }\end{array}$ \\
\hline COL002 & + & + & - & + & - & + & - & + & - & None & $\begin{array}{l}\text { Streptococcus } \\
\text { bovis biotype } \\
\text { II } / 2\end{array}$ & $\begin{array}{l}\text { Streptococcus } \\
\text { bovis } \\
\text { biotype } \mathrm{II} / 2\end{array}$ \\
\hline MG6 & - & w & - & + & - & - & - & + & + & None & $\begin{array}{l}\text { Streptococcus } \\
\text { bovis biotype } \\
\text { II } / 2 \text { or } \\
\text { Streptococcus } \\
\text { salivarius }\end{array}$ & $\begin{array}{c}\text { Streptococcus } \\
\text { bovis } \\
\text { biotype II/2 }\end{array}$ \\
\hline MGSoph & + & + & - & + & - & - & - & + & + & Sal & $\begin{array}{l}\text { Streptococcus } \\
\text { bovis biotype } \\
\text { II/2 }\end{array}$ & $\begin{array}{l}\text { Streptococcus } \\
\text { bovis } \\
\text { biotype II/2 }\end{array}$ \\
\hline MGLars & - & - & - & + & - & - & - & + & + & None & $\begin{array}{l}\text { Streptococcus } \\
\text { bovis biotype } \\
\text { II } / 2 \text { or } \\
\text { Streptococcus } \\
\text { salivarius }\end{array}$ & $\begin{array}{c}\text { Streptococcus } \\
\text { bovis } \\
\text { biotype } \mathrm{II} / 2\end{array}$ \\
\hline MG20 & - & - & - & + & - & - & - & + & w & None & $\begin{array}{l}\text { Streptococcus } \\
\text { bovis biotype } \\
\text { II } / 2 \text { or } \\
\text { Streptococcus } \\
\text { salivarius }\end{array}$ & $\begin{array}{c}\text { Streptococcus } \\
\text { bovis } \\
\text { biotype II } / 2\end{array}$ \\
\hline
\end{tabular}


TABLE 2-Continued

\begin{tabular}{|c|c|c|c|c|c|c|c|c|c|c|c|c|}
\hline \multirow[b]{2}{*}{ Strain } & \multicolumn{9}{|c|}{ Biochemical tests } & \multirow{2}{*}{$\begin{array}{l}\text { Colony } \\
\text { morph- } \\
\text { ology }\end{array}$} & \multicolumn{2}{|c|}{ Identity as determined by: } \\
\hline & $\begin{array}{l}\beta \text {-Glucu- } \\
\text { ronidase }\end{array}$ & $\begin{array}{l}\beta \text {-Galac- } \\
\text { tosidase }\end{array}$ & $\begin{array}{l}\text { Man- } \\
\text { nitol }\end{array}$ & $\begin{array}{c}\text { Tre- } \\
\text { halose }\end{array}$ & Inulin & Starch & Glycogen & $\begin{array}{l}\text { Bile- } \\
\text { esculin }\end{array}$ & $\begin{array}{l}\text { Group } \\
\text { D anti- } \\
\text { serum }^{b}\end{array}$ & & $\begin{array}{l}\text { Rapid strep } \\
\text { system }\end{array}$ & $\begin{array}{c}\text { DNA } \\
\text { hybridization }\end{array}$ \\
\hline MG565 & - & - & - & + & - & - & - & + & - & None & $\begin{array}{l}\text { Streptococcus } \\
\text { bovis biotype } \\
\text { II } / 2 \text { or } \\
\text { Streptococcus } \\
\text { salivarius }\end{array}$ & $\begin{array}{l}\text { Streptococcus } \\
\quad \text { bovis } \\
\quad \text { biotype II/2 }\end{array}$ \\
\hline CDC007 & + & + & - . & + & - & - & - & + & - & None & $\begin{array}{l}\text { Streptococcus } \\
\text { bovis biotype } \\
\text { II/2 or } \\
\text { Streptococcus } \\
\text { salivarius }\end{array}$ & Uncertain \\
\hline
\end{tabular}

${ }^{a}$ All Streptococcus bovis strains were positive for acetoin, esculin, $\alpha$-galactosidase, leucine arylamidase, lactose, and raffinose and negative for hippurate, pyrrolidonylarylamidase, alkaline phosphatase, arginine, ribose, arabinose (except strain COL005), and sorbitol.

${ }^{b}$ Reaction with Lancefield group $\mathrm{D}$ antiserum, as determined in a latex bead agglutination system.

' Bov, Colonies resemble colonies of typical Streptococcus bovis biotype I strains; Sang, colonies resemble the hard adherent colonies of Streptococcus sanguis; Sal, colonies typical of Streptococcus salivarius strains; None, flat or low convex colonies apparently devoid of polysaccharide.

${ }^{d}+$, Positive reaction; - , negative reaction; $w$, weak reaction.

${ }^{e}$ NI, Not identified.

gous control; values were expressed as percentages, the homologous control value being $100 \%$.

In the first experiments, type HAWP filters $(25 \mathrm{~mm}$; Millipore Corp., Bedford, Mass.) were used, but in later experiments we used type HAHY filters. We found that these filters bound about twice as much single-stranded DNA as the type HAWP filters and released proportionally less DNA during incubation.

\section{RESULTS}

Characteristics of Streptococcus salivarius. Table 1 lists all of the strains that were identified as Streptococcus salivarius by biochemical tests or DNA homology or both, along with one strain of uncertain identity. All of these streptococci were positive for leucine arylamidase, $\beta$-galactosidase (except strain $\mathrm{AC002}$ ), and lactose and negative for hippurate, pyrrolidonylaryladmidase, $\beta$-glucuronidase; alkaline phosphatase, arginine, ribose, arabinose, mannitol, sorbitol, and glycogen (except strain CDC009). The reactions that were variable, colony morphology, and the extents of DNA hybridization as percentages of the homologous control are shown in Table 1. The Rapid Strep system gave an incorrect identification if a strain failed to produce acetoin (VogesProskauer test) and did not accept strain CDC009 because of its acidification of glycogen. Strain CDC015 fermented few sugars and was not identified; the identity of ths strain was uncertain by DNA also. Of the 14 strains that were genetically related, only strain COLO01 had neither the colony morphology nor the biochemical profile of Streptococcus salivarius. We believe that strain UC8105 is a Streptococcus salivarius strain and suspect that its DNA preparation was of poor quality.

Table 1 does not show the levels of homology between strain KB005 DNA and DNAs from six Streptococcus bovis strains. All of these values were very low (between 25 and $38 \%$ ).

Streptococcus bovis biotypes. The strains identified as Streptococcus bovis and their phenotypic characters are shown in Table 2, and the DNA hybridization data for these strains are shown in Table 3. All Streptococcus bovis strains were positive for acetoin, esculin, and $\alpha$-galactosidase and negative for hippurate, pyrrolidonylarylamidase, alkaline phosphatase, arginine, ribose, arabinose (except strain COL005), and sorbitol. Four strains were typical of Streptococcus bovis biotype I in their ability to ferment mannitol. One strain did not grow on bile-esculin agar, and two had nontypical colony morphologies.

Streptococcus bovis biotype II strains did not ferment mannitol or inulin, and most did not ferment starch or glycogen. The Rapid Strep system recognized two subtypes of Streptococcus bovis biotype II. Six of our strains were identified as Streptococcus bovis biotype II/1, and eight were called Streptococcus bovis biotype II/2. There were very few differences between Streptococcus bovis biotype II/1 and Streptococcus bovis biotype II/2. One-half of the biotype II/ 2 strains but none of the biotype II/1 strains produced $\beta$ glucuronidase. Fermentation of starch and glycogen was more common among biotype II/1 strains. The most consistent biochemical difference between the two biotypes involved fermentation of trehalose. All Streptococcus bovis biotype II/2 strains acidified this sugar, but Streptococcus bovis biotype II/ 1 strains did not.

In many cases the identification of Streptococcus bovis biotype II strains was not explicit when the Rapid Strep system was used. In each case the bacterium had a biochemical profile similar to that of Streptococcus salivarius. However, the "percent identification," a term used by the system to express the level of confidence in an identification, always favored Streptococcus bovis over Streptococcus salivarius in these equivocal cases. Interestingly, the Rapid Strep system never confused Streptococcus bovis biotype II/1 with Streptococcus bovis biotype II/2. One strain, strain COL005, was not identified. Presumably this was because it fermented arabinose; it was otherwise typical of Streptococcus bovis biotype II/1 strains. Fermentation of arabinose is common in Streptococcus bovis strains isolated from animals (see below)

The variety of colony forms produced by both Streptococcus bovis and Streptococcus salivarius on sucrose agar indicated that colonial morphology alone is not reliable for identifying these streptococci. None of the strains was $\beta$-hemolytic. As noted by other workers $(6,17,37)$, many Streptococcus bovis strains do not react with group D 
TABLE 3. DNA-DNA Hybridization among strains of Streptococcus bovis ${ }^{a}$

\begin{tabular}{|c|c|c|c|c|}
\hline \multirow{3}{*}{$\begin{array}{c}\text { Source of } \\
\text { unlabeled DNA }\end{array}$} & \multicolumn{4}{|c|}{$\%$ Hybridization with labeled DNA from: } \\
\hline & \multicolumn{2}{|c|}{$\begin{array}{l}\text { Streptococcus } \\
\text { bovis biotype I } \\
\text { strain CDC003 }\end{array}$} & \multirow{2}{*}{$\begin{array}{l}\text { Streptococcus } \\
\text { bovis biotype } \\
\text { II/1 strain } \\
\text { COL003 }\end{array}$} & \multirow{2}{*}{$\begin{array}{c}\text { Streptococcus } \\
\text { bovis biotype } \\
\text { II } / 2 \text { strain } \\
\text { CDC008 }\end{array}$} \\
\hline & Expt 1 & Expt 2 & & \\
\hline \multicolumn{5}{|l|}{$\begin{array}{c}\text { Streptococcus } \\
\text { bovis } \\
\text { biotype I }\end{array}$} \\
\hline $\mathrm{CDC} 003$ & 100 & 100 & 38 & 90 \\
\hline $\mathrm{CDC} 001$ & 102 & & & \\
\hline $\mathrm{CDC} 002$ & 100 & & & \\
\hline MGEthe & 123 & & & \\
\hline \multicolumn{5}{|l|}{$\begin{array}{c}\text { Streptococcus } \\
\text { bovis } \\
\text { biotype } \\
\text { II } / 1\end{array}$} \\
\hline COL003 & & 56 & 100 & \\
\hline CDC011 & 61 & 32 & 116 & 73 \\
\hline $\mathrm{CDC} 012$ & & & 76 & \\
\hline COL005 & & 56 & 84 & \\
\hline MGFras & 71 & & 117 & 75 \\
\hline CDC018 & 55 & & 103 & 55 \\
\hline \multicolumn{5}{|l|}{$\begin{array}{c}\text { Streptococcus } \\
\text { bovis } \\
\text { biotype } \\
\text { II } / 2\end{array}$} \\
\hline $\mathrm{CDC} 008$ & 85 & 63 & 40 & 100 \\
\hline COL002 & 85 & 127 & & 92 \\
\hline MG6 & & 113 & & \\
\hline MGSoph & & 87 & & \\
\hline MGLars & & 106 & & \\
\hline MG20 & & 99 & & \\
\hline MG565 & & 97 & & \\
\hline $\mathrm{CDC} 007$ & & 40 & & \\
\hline E. coli & 7 & 9 & 8 & 9 \\
\hline Blank & 8 & 8 & 7 & \\
\hline
\end{tabular}

${ }^{a}$ Data are expressed as percentages of the homologous control value.

antibody in the commercial agglutination system that we used.

Hybridization among Streptococcus bovis biotypes. The four strains of Streptococcus bovis biotype I were genetically homologous with each other (Table 3). The same experiment indicated that some strains of Streptococcus bovis biotype II were homologous with Streptococcus bovis biotype I, since their DNAs hybridized extensively (85\%) with labeled DNA of Streptococcus bovis biotype I strain CDC003. Additional experiments showed that all strains of Streptococcus bovis biotype II/2 (except strain CDC007) were homologous with each other and with Streptococcus bovis biotype I strain CDC003, but not with strains of Streptococcus bovis biotype II/1 and that Streptococcus bovis biotype II/1 strains formed a separate group whose DNAs all hybridized well with labeled DNA from Streptococcus bovis biotype II/1 strain COL003, whereas DNAs from Streptococcus bovis biotype I strain CDC003 and Streptococcus bovis biotype II/2 strain CDC008 did not. Two experiments (data not shown) showed that Streptococcus bovis biotype II/2 strain CDC007 was not related to Streptococcus salivarius or Streptococcus bovis biotype II/1. The failure of the DNA of this strain to hybridize with other Streptococcus bovis biotype II/2 DNAs may have been purely technical. DNA from Streptococcus bovis never hybridized appreciably with Streptococcus salivarius DNA; the highest value was $36 \%$, and all other values were below $30 \%$.

Overall, the identifications of the senders agreed with identifications based on DNA data or the Rapid Strep system or both, but hybridization clarified the identities of some atypical isolates. Strain CDC009 was like Streptococcus bovis biotype II with respect to glycogen acidification but was actually a Streptococcus salivarius strain, and strain CDC018, which resembled Streptococcus salivarius because of its colonies on sucrose agar and its failure to grow on bile-esculin agar, proved to be a Streptococcus bovis biotype II/1 strain. The production of glucan by strain COL005 (= NCTC 8133 ) is probably the reason why this strain was originally classified as a Streptococcus bovis biotype I strain.

DNA base contents. There were no differences in the DNA base contents of the Streptococcus bovis genotypes or Streptococcus salivarius strains. The values obtained for Streptococcus salivarius strains were $43.4 \pm 1.31 \mathrm{~mol} \%$ $\mathrm{G}+\mathrm{C}$ (mean \pm standard deviation; range, 41.7 to 45.3 mol\%); the values obtained for Streptococcus bovis biotype I were $42.8 \pm 1.18 \mathrm{~mol} \% \mathrm{G}+\mathrm{C}$ (range, 41.8 to $44.7 \mathrm{~mol} \%$ ); the values obtained for Streptococcus bovis biotype II/1 were $42.2 \pm 1.08 \mathrm{~mol} \% \mathrm{G}+\mathrm{C}$ (range, $41.4 \pm 44.4 \mathrm{~mol} \%$ ); and the values obtained for Streptococcus bovis biotype II/2 were $42.7 \pm 1.04 \mathrm{~mol} \% \mathrm{G}+\mathrm{C}$ (range, 40.5 to $43.6 \mathrm{~mol} \%$ ).

\section{DISCUSSION}

Our results show that Streptococcus salivarius strains are genetically quite homologous despite some phenotypic heterogeneity and that this species is not related to Streptococcus bovis. Streptococcus bovis biotypes I and II/2 are genetically the same and represent a single species. Streptococcus bovis biotype II/1 strains are distinctly different. The levels of hybridization of the DNAs of these strains with biotype I and II/2 DNAs were at most 70 to $75 \%$ and usually were lower. When Streptococcus bovis biotype II/1 strain COL003 DNA was the labeled DNA, the level of hybridization with Streptococcus bovis biotype I strain CDC003 DNA or Streptococcus bovis biotype II/2 strain CDC008 DNA was about $40 \%$. Thus, there are some DNA base sequences in biotype II/1 strains that are similar to sequences in biotype I and II/2 strains. At this level of genetic similarity we would consider biotype II/1 strains members of a subspecies of Streptococcus bovis.

All of our Streptococcus bovis strains were of human origin, and our results should not be extrapolated to the Streptococcus bovis strains isolated from animals. Animal strains are biochemically somewhat different; many ferment arabinose but not mannitol, and glucan production correlates more with arabinose fermentation than with mannitol fermentation $(11,29)$. It was these streptococci, not the mannitol fermenters, that Orla-Jensen called Streptococcus bovis $(33,39$; reviewed by Kiel and Skadhauge [22], who cited Friedberg [17]). Furthermore, the animal isolates themselves are genetically heterogeneous (18).

Our results demonstrate the following phenomena that we and other workers have observed in streptococci: there can be genetic heterogeneity among phenotypically similar streptococci, and there can be genetic homology in streptococci that are phenotypically diverse. There is great genetic diversity among the phenotypically similar members of the mutans group $(4,9)$. Conversely, Welborn et al. (41) found genetic homogeneity among six strains of the Streptococcus constellatus-Streptococcus intermedius group (or "Streptococcus milleri" [3]) that were heterogeneous with respect to hemolysis, Lancefield group, and action on lactose, esculin, 
and starch. In the case of Streptococcus bovis, we found genetic homology between two distinct biotypes (biotypes I and $\mathrm{II} / 2$ ) but a lack of strong relationship between two biotypes that have only a few biochemical differences (biotypes II/1 and II/2). Our results also show that within Streptococcus salivarius there are strains that are hard to recognize as Streptococcus salivarius, yet are genetically homologous with typical strains. Moreover, Streptococcus salivarius DNA is indistinguishable from Streptococcus thermophilus DNA (16). This phenomenon illustrates how little of the bacterial chromosome is required to produce the characteristics that we observe.

Because of the relationship between Streptococcus bovis and colon diseases $(23,24,31,36)$, it is important to differentiate Streptococcus bovis from Streptococcus salivarius in clinical isolates. Typical strains and isolates of Streptococcus salivarius and Streptococcus bovis are not difficult to identify. However, there are isolates of Streptococcus salivarius that grow on bile-esculin medium, and some produce group D reactions and thus mimic Streptococcus bovis. Conversely, some Streptococcus bovis isolates are bile-esculin medium negative, and many do not give a group $\mathrm{D}$ reaction with commonly used agglutination systems $(6,15,37)$. These problems were reviewed by Ruoff et al. (37), who found that the group D reaction of Streptococcus salivarius was caused by a cross-reacting antigen and that the true group D antigen of Streptococcus bovis could be demonstrated in hot acid extracts. In some cases the antigen required concentration by alcohol precipitation. These authors further emphasized the importance of an adequate number of tests to insure proper identification of these two species.

Although we do not recommend a commercial rapid identification system for strictly describing species of streptococci, the one used in this study was useful for identification, and it provided biochemical profiles which helped to delineate the two genetic groups of Streptococcus bovis.

\section{ACKNOWLEDGMENTS}

We are grateful to G. Colman, R. R. Facklam, and K. L. Ruoff for giving us material and to Lawrence J. Kunz for his encouragement. We thank C. Manna and M. Latham for preparing the manuscript.

This work was supported by the University of Connecticut Research Foundation and by Public Health Service grant DE07126 from the National Institute for Dental Research.

\section{LITERATURE CITED}

1. Appelbaum, P. C., P. S. Chaurushiya, M. R. Jacobs, and A. Duffett. 1984. Evaluation of the Rapid Strep system for species identification of streptococci. J. Clin. Microbiol. 19:588-591.

2. Bailey, R. W., and A. E. Oxford. 1958. A quantitative study of the production of dextran from sucrose by rumen strains of Streptococcus bovis. J. Gen. Microbiol. 19:130-145.

3. Ball, L. C., and M. T. Parker. 1979. The cultural and biochemical characters of Streptococcus milleri strains isolated from human sources. J. Hyg. 82:63-78.

4. Beighton, D., H. Hayday, R. R. B. Russell, and R. A. Whiley. 1984. Streptococcus macacae sp. nov. from dental plaque of monkeys (Macaca fascicularis). Int. J. Syst. Bacteriol. 34: 332-335.

5. Carlsson, J. 1971. Nutritional requirements of Streptococcus salivarius. J. Gen. Microbiol. 67:69-76.

6. Chang, G. T., and P. D. Ellner. 1983. Evaluation of slide agglutination methods for identifying group D streptococci. J. Clin. Microbiol. 17:804-806.

7. Colman, G., and L. C. Ball. 1984. Identification of streptococci in a medical laboratory. J Appl. Bacteriol. 57:1-14.

8. Coykendall, A. L. 1970. Base composition of deoxyribonucleic acid isolated from cariogenic streptococci. Arch. Oral Biol. 15:365-368

9. Coykendall, A. L. 1977. Proposal to elevate the subspecies of Streptococcus mutans to species status, based on their molecular composition. Int. J. Syst. Bacteriol. 27:26-30.

10. Coykendall, A. L., F. S. Kaczmarek, and J. Slots. 1980. Genetic heterogeneity in Bacteroides asaccharolyticus (Holdeman and Moore, 1970), Finegold and Barnes 1977 (Approved Lists, 1980) and proposal of Bacteroides gingivalis $\mathrm{sp}$. nov. and Bacteroides macacae (Slots and Genco) comb. nov. Int. J. Syst. Bacteriol. 30:559-564.

11. Dain, J. A., A. L. Neal, and H. W. Seeley. 1956. The effect of carbon dioxide on polysaccharide production by Streptococcus bovis. J. Bacteriol. 72:209-213.

12. DeLey, J., and R. Tijtgat. 1970. Evaluation of membrane filters for DNA-DNA hybridization. Antonie van Leeuwenhoek J. Microbiol. Serol. 36:461-474.

13. Facklam, R. R. 1972. Recognition of group D streptococcal species of human origin by biochemical and physiological tests. Appl. Microbiol. 23:1131-1139.

14. Facklam, R. R., R. C. Cooksey, and E. C. Wortham. 1979. Evaluation of commercial latex agglutination reagents for grouping streptococci. J. Clin. Microbiol. 10:641-646.

15. Facklam, R. R., D. L. Rhoden, and P. B. Smith. 1984. Evaluation of the Rapid Strep system for the identification of clinical isolates of Streptococcus species. J. Clin. Microbiol. 20:894898.

16. Farrow, J. A. E., and M. D. Collins. 1984. DNA base composition, DNA-DNA homology and long-chain fatty acid studies on Streptococcus thermophilus and Streptococcus salivarius. J. Gen. Microbiol. 130:357-362.

17. Friedberg, R. 1941. Studier over ikke-haemolytiske streptokokker. Einer Munksgaard Forlag, Copenhagen.

18. Garvie, E. I., and A. J. Bramley. 1979. Streptococcus bovis-an approach to its classification and its importance as a cause of bovine mastitis. J. Appl. Bacteriol. 46:557-566.

19. Haldane, E. V., J. H. Haldane, G. Digout, A. West, and C. E. van Rooyen. 1974. Streptococcus bovis endocarditits. Can. Med. Assoc. J. 111:678-682.

20. Hoppes, W. L., and P. I. Lerner. 1974. Nonenterococcal group D endocarditis caused by Streptococcus bovis. Ann. Intern. Med. 81:588-593.

21. Kelstrup, J. 1981. Extracellular polysaccharides of smooth and rough variants of Streptococcus salivarius. Scand. J. Dent. Res. 89:374-383.

22. Kiel, P., and K. Skadhauge. 1973. Studies on mannitol-fermenting strains of Streptococcus bovis. Acta Pathol. Microbiol. Scand. Sect. B 81:10-14.

23. Klein, R. S., M. T. Catalano, S. C. Edberg, J. I. Casey, and N. H. Steigbigel. 1979. Streptococcus bovis septicemia and carcinoma of the colon. Ann. Intern. Med. 91:560-562.

24. Klein, R. S., R. A. Recco, M. T. Catalano, S. C. Edberg, J. I. Casey, and N. H. Steigbigel. 1977. Association of Streptococcus bovis with carcinoma of the colon. N. Engl. J. Med. 297: 800-802.

25. Legault-Démare, J., B. Desseaux, T. Heyman, S. Seror, and G. P. Ress. 1967. Studies on hybrid molecules of nucleic acids. I. DNA-DNA hybrids on nitrocellulose filters. Biochem. Biophys. Res. Commun. 28:550-557.

26. Mac Faddin, J. R. 1977. Biochemical tests for the identification of medical bacteria. The Williams \& Wilkins Co., Baltimore.

27. Marmur, J. 1961. A procedure for the isolation of deoxyribonucleic acid from microorganisms. J. Mol. Biol. 3:208-218.

28. Marmur, J., and P. Doty. 1962. Determination of the base composition of deoxyribonucleic acid from its thermal denaturation temperature. J. Mol. Biol. 5:109-118.

29. Medrek, T. F., and E. M. Barnes. 1962. The physiological and serological properties of Streptococcus bovis an related organisms isolated from cattle and sheep. J. Appl. Bacteriol. 25:169-179.

30. Moellering, R. C., Jr., B. K. Watson, and L. J. Kunz. 1974. 
Endocarditis due to group D streptococci. Am. J. Med. 57:239-250.

31. Murray, H. W., and R. B. Roberts. 1978. Streptococcus bovis bacteremia and underlying gastrointestinal diseases. Arch. Intern. Med. 138: 1097-1099.

32. Niven, C. F., Jr., K. L. Smiley, and J. M. Sherman. 1941. The production of large amounts of a polysaccharide by Streptococcus salivarius. J. Bacteriol. 41:479-484.

33. Orla-Jensen, S. 1919. The lactic acid bacteria. Mem. Acad. R. Sci. Danemark Sect. Sci. Ser. 8 5:81-197.

34. Parker, M. T., and L. C. Ball. 1976. Streptococci and aerococci associated with systemic infection in man. J. Med. Microbiol. 9:275-301.

35. Ravreby, W. D., E. J. Bottone, and G. T. Keusch. 1973. Group $\mathrm{D}$ streptococcal bacteremia with emphasis on the incidence and presentation of infections due to Streptococcus bovis. N. Engl. J. Med. 289:1400-1403.

36. Reynolds, J. G., E. Silva, and W. M. McCormack. 1983 Association of Streptococcus bovis bacteremia with bowel disease. J. Clin. Microbiol. 17:696-697.
37. Ruoff, K. L., M. J. Ferraro, J. Holden, and L. J. Kunz. 1984. Identification of Streptococcus bovis and Streptococcus salivarius in clinical laboratories. J. Clin. Microbiol. 20:223-226.

38. Ruoff, K. L., and L. J. Kunz. 1983. Use of the Rapid STREP system for identification of viridans streptococcal species. J. Clin. Microbiol. 18:1138-1140.

39. Sherman, J. M. 1937. The streptococci. Bacteriol. Rev. 1:3-97.

40. Tanzer, J. M., and J. Fisher. 1982. Competition of a rough non-cariogenic Streptococcus mutans in dental plaque, p. 124-125. In S. E. Holm and P. Christensen (ed.), Basic concepts of streptococci and streptococcal diseases. Reedbooks Ltd., Chertsey, Surrey, United Kingdom.

41. Welborn, P., W. K. Hadley, E. Newbrun, and D. Yajko. 1983. Characterization of strains of viridans streptococci by deoxyribonucleic acid hybridization and physiological tests. Int. J. Syst. Bacteriol. 33:293-299.

42. Whittenbury, R. 1964. Hydrogen peroxide formation and catalase activity in the lactic acid bacteria. J. Gen. Microbiol. $35: 13-26$. 